\title{
Prospecting Collection and Ethnobotanical Studies of Traditional Rice Varieties in Guinea
}

\author{
Mamadou Laho Barry ${ }^{1,2}$, Kiswendsida Romaric Nanema ${ }^{1}$, Kouka Fidèle Tiendrebéogo ${ }^{1}$, \\ Nerbéwendé Sawadogo ${ }^{*}$, Mahamadi Hamed Ouedraogo', Mamadou Billo Barry ${ }^{2}$, \\ Pauline Bationo-Kando ${ }^{1}$ and Mahamadou Sawadogo ${ }^{1}$
}

${ }^{1}$ Université Joseph KI-ZERBO, Ecole Doctorale Sciences et Technologies, Laboratoire Biosciences, Equipe Génétique et Amélioration des Plantes (EGAP), Burkina Faso

${ }^{2}$ Institut de Recherche Agronomique de Guinée (IRAG), Guinée Conakry

*Corresponding author

\section{A B S T R A C T}

\section{Keywords}

Varietal diversity, Diversity indices, NERICA, CK, ARICA and iron toxicity

\section{Article Info}

Accepted:

10 November 2019

Available Online:

10 December 2019
The diagnosis of places of varietal diversity of rice in Guinea was made from survey data from several farms in 41 villages themselves distributed in the 2 natural regions of Lower Guinea and Forest Guinea. The descriptors used are the number of known varieties and varieties cultivated at different scales, as well as their utilization rate. The latter makes it possible to classify the Sativa and Glaberrima varieties at the village level and to identify improved and local varieties of notoriety. Diversity indices derived from the adaptation of parameters used by ecologists to describe biodiversity in the natural environment have made it possible to better understand the risks of loss of diversity. Varietal diversity is very important, particularly in the two regions of old rice-growing tradition, forest Guinea and lower Guinea. But it is also fragile because of the low rate of use of a large number of varieties and their lack of knowledge. As this structuring of diversity is shaped by the great diversity of agro-systems and the poor control of other production factors by farmers, the risk of loss of diversity seems limited in the current context. The fairly widespread adoption of recently released improved varieties (CK, NERICA and ARICA) does not translate into a reduction in the number of pre-existing crop varieties. Complementary to the latter, in particular by their tolerance to biotic and abiotic stresses (iron toxicity, pyrolysis and drought), they seem to be rather an enrichment of varietal diversity in Guinea.

\section{Introduction}

Guinea is one of the largest rice producing countries in West Africa. Rice cultivation is a very old tradition in this country. Eustachian stories from the Pit "Traveling on the West
Coast of Africa" (1479-1480) attest to largescale rice cultivation in Guinea long before the Portuguese introduced Asian rice varieties, Oryza sativa. The rice sample observed by Steud (1885) to create and describe the rice species cultivated in Africa, Oryza 
glaberrima, came from Guinea (Godon 1991, Porte 1955). Thanks to the diversity of rice ecosystems, Guinea is an important reservoir of rice genetic diversity in West Africa (Ghesquière and Second, 1983).

The country is considered a center of diversity of O. Glaberrima (Porte d'Is, 1950) and the most important site for in situ conservation of African rice species (Bezançon, 1995).

The regions of Lower Guinea and Forest Guinea are the most emblematic natural regions of Guinea among the four natural regions with regard to the diversity of rice growing systems. Several types of rice cultivation are present: rainfed rice in a slashand-burn system, lowland rice, lowland rice, interior valley and mangrove rice with varying degrees of crop exposure to soil and salinity of water (Beavogui et al., 2000).

The interpenetration of different rice ecosystems resulted in the coexistence of the two cultivated species, which could lead to an original genetic diversity by interspecific recombination.

In addition, recent public efforts to improve rice productivity in these two regions have led to the introduction of new varieties, including modern rice varieties. This process may lead to the replacement of local varieties with modern, high yielding varieties and thus endanger the conservation of local genetic resources.

The importance of the genetic diversity of rice in these areas has prompted the Guinea Agricultural Research Institute (IRAG) to develop conservation strategies. Also, this study aims to better understand the peasant management methods of rice varieties grown in the regions of Lower Guinea and Forest Guinea and to build a gene bank of these varieties.

\section{Materials and Methods}

\section{Prospecting areas}

The survey was conducted in villages representative of the main lowland rice growing areas in Guinea, namely the region of Kindia in Lower Guinea (zone 1) and the Macenta region in Forest Guinea (zone 2). Forty one (41) villages were covered to report on the agro-ecological diversity of two regions including 17 villages in Kindia and 24 in Macenta. Based on data from iron toxicity studies in Lower Guinea and Forest Guinea. In each village, an inventory of rice varieties was conducted.

The Kindia Region is one of Guinea's four natural regions covering an area of $8.828 \mathrm{~km}^{2}$ with an estimated population of 498.203, (D.N.S., 2010). It is located in the East of Lower Guinea and consists of ten rural communes and one urban commune. It is $458.13 \mathrm{~m}$ above sea level, in transition between Lower and Middle Guinea (National Monograph, 2000). Kindia is an area very favorable to agriculture practiced at more than $80 \%$ practiced by the population with an average rainfall of $2500 \mathrm{~mm}$ spread over about 150 days of rain. Rice cultivation is the main crop among cereals. Lowland, upland and alluvial plains ecosystems are found.

The prefecture of Macenta is an administrative subdivision of the Nzérékoré region in Forest Guinea. It covers an area of $8.600 \mathrm{~km}^{2}$ for a population of 296.000 inhabitants. Macenta is located south of the capital Conakry at 801 $\mathrm{km}$. It is an area very favorable to agriculture through the richness of soils nutrients and abundant rainfall (2000-3500 mm of water per year) with 8 months of rain from March to October longer than in Lower Guinea. It is subdivided into 15 rural development communes plus the urban municipality of Macenta. The soils encountered are hydro- 
morphic lowland soils, ferralitic soils of plateaus. The cultivation of rice remains the main cereal grown in this zone. In addition, there are cash crops such as coffee, cocoa, oil palm and rubber.

\section{Collection of accessions and ethnobotany survey}

Ethnobotanical surveys coupled with prospecting-collection were conducted between 2017 and 2018 in these two regions. During these activities, the Heads of the Centers and Research Stations, the Technical Support Zone (ZAT) agents and the translator guides were asked in each locality for the identification of the different growing areas and the translation of certain terms. Thus, in the zone of Kindia (zone 1), ten (10) rural development communes (CRD) were covered by the respondents and in the Macenta zone (Zone 2), six (6) rural development communes (CRD) and an urban commune were covered by the surveys.

For each variety, a seed sample was collected from farmers holding local varieties. For each variety, only $100 \mathrm{~g}$ were collected because the fields were already harvested. Before sampling, the research team determined whether the variety belonged to $O$. glaberrima or $O$. sativa, based on the shape of the seed. Sampling focused only on traditional lowland rice varieties in all collection areas. Several samples were taken from several accessions. Each sample is followed by an interview with the farmer who provided the samples.

\section{Collected data}

During the survey, a fact sheet gathered the following information: the name of the farmer, the local name of the accession, the origin of the seeds, the development cycle, cropping techniques, pest attacks and performances agronomic. To this, add other information such as the name of the site (locality), the CRD, the date of collection of the samples, the geographical coordinates. To obtain the data, a direct interview method was adopted for randomly selected individuals in each locality. Thus, the accessions were collected from the producers. During the collection periods, all the fields were already harvested. Each collected accession was tagged and kept in an envelope and in plastic bags. In table 1, the farmers surveyed are distributed according to age, sex and activity.

\section{Analysis of collected data}

The data collected is essentially qualitative. The Excel 2007 software was used to capture and process the different data collected during the ethnobotanical survey and to produce the table 1-8 and figures. They are analyzed by geographical area, by locality or village, or by ethnic group using descriptive statistics. The data thus prepared were the subject of frequency calculations and were used to construct the various patterns or histograms of the identification criteria of the local varieties, the number of varieties identified on the basis of these criteria (shape and color of the seeds, provenance and resistance to stress), the importance of growing rice and lowlands in different collection locations.

\section{Results and Discussion}

Variation in the number of rice accessions collected and classification of accessions collected.

The number of accessions found varies from one region to another depending on the identification criteria used by producers. Thus, during the 2017 crop year, 43 accessions were collected in 17 villages in the Kindia region and 47 accessions in 24 villages in the Macenta region. A total of 90 accessions were collected, all of which are lowland rice 
varieties. On the basis of seed form and cycle, 72 accessions are $O$. sativa and 18 are $O$. glaberrima. The minimum amount of sample collected is $100 \mathrm{~g}$ of rice per accession.

In addition, farmers recognize that the number of varieties grown in their villages has increased in recent years. This increase is a function of the introduction of new varieties (improved varieties) per village each year. The number of varieties of Oryza glaberrima remained stable while that of Oryza sativa increased (Fig. 1 and 2).

Diversity of vernacular names or names of rice in local languages

Several peasant nomenclature names were identified from three (3) ethnic groups surveyed in the Kindia region and from six (6) ethnic groups surveyed in the Macenta region (Table 2). In the majority of ethnic groups, rice (O. sativa or $O$. glaberrima) is designated by the same vernacular name. On the other hand, for each ethnic group, given the large number of rice varieties encountered, each variety is identified by a separate name that varies according to its source.

\section{Criteria for denomination of local or peasant varieties of rice}

In most respondents and regardless of the ethnic group, the denomination criteria of the local varieties are related to the provenance or probable origin of the first seeds, the morphological characters and the use of the rice and the resistance of the plant to the different stresses (Figure 3). The majority of respondents use mostly morphological characters to identify accessions or varieties. For example, 55\% use seed and leaf traits such as shape and color, and $25 \%$ indicate the provenance or probable origin of the seed, the village, district, or city. On the other hand, a minority, namely $12.5 \%$ of the respondents use the use of rice and $7.5 \%$, the resistance to different stresses for the denomination of the peasant varieties.

Depending on the cycle and the number of respondents, the accessions collected are between 3 and 6 months of the 130 producers surveyed in the Kindia region and 4 to 7 months among the 120 producers surveyed in the Macenta region (see table 3).

The results showed that in Guinea, rice is grown in all ecosystems. In fact, the production areas in order of importance are the pluvial plateau or hillside (slash and burn) representing the majority of cultivated areas (65\%), the mangrove (16\%), the lowland (10\%) and alluvial plains occupy the lowest proportion of cultivated area (9\%).

\section{Main areas of lowland rice cultivation in Guinea}

Among the four natural regions of Guinea, lowland rice cultivation is much more common in the regions of Lower Guinea and Forest Guinea. In fact, these two regions are full of more slums in Guinea. The cultural practice is purely archaic because rice systems are still extensive systems in which the use of agricultural inputs (certified seeds, fertilizers and herbicides), irrigation and mechanization are very marginal. Rainfall is the only source of water for the rice crop. Cultivation is manual, with the exception of a few cases of mechanization of soil preparation work on the tractor. Depending on the degree of water control, two cropping systems are encountered: the lowland rice cultivation system and the undeveloped lowland rice cultivation system. Of the two, the unmanaged system is the most important in terms of cultivated area. However, the surfaces of the lowland cultivation system are increasing year by year thanks to the intervention of the State or NGOs. These systems are found in the two 
natural regions of forest Guinea and lower Guinea (the two most mountainous regions). Traditional varieties are dominant in undeveloped lowlands while in improved lowlands, improved varieties predominate. In general, rice is sown on the fly in the undeveloped shallows and transplanted into shallows on manual tillage or, very rarely, in the tractor. Weeds and iron toxicity are the main constraints of this type of rice cultivation.

Harvests are mainly for self-consumption. However, com volumes increasingly, merchandising is increasing thanks to improvements in the road network, local rice incentive prices and the very significant increase in mechanical husking machines that make it easier for women to machine rice.

\section{How to obtain the seeds or origin of cultivated varieties}

Table 5 shows the methods of obtaining and/or supplying seeds of known varieties in the villages studied during our surveys. Farmers do not know the origin of most varieties. Very few varieties are native to the village where they are grown, and so is not the product of local breeding. Nevertheless, in all the villages of the two surveyed regions, nearly $15 \%$ of the varieties were selected in the village according to the producers. The majority of the varieties $(85 \%)$ come from neighboring or distant villages. In both regions, introductory of all varieties encountered in their villages are not known. In Kindia, it is men who provide the bulk of the varietal introduction, while in Macenta, women introduce many more varieties than men, $25 \%$ against $15 \%$. These results are consistent with the observation that in Macenta, village of the Toma ethnic group, rice cultivation is mainly managed by women, whereas in Kindia, among the soussous, it is the men who manage the cultivation of rice.
Generally in these two regions, varietal exchanges are based on relationships between producers (see table 6).

\section{Mode of supply of seeds of local varieties}

In farmer settings, the seed supply system can be formal or informal. The seed supply process of the sample of farmers monitored in both regions is rather informal. With this system, each producer organizes himself every year to mobilize the seeds he needs.

At harvest, each producer makes up his seed stock. He takes from each of the varieties that he plans to repeat the following year the amount he deems sufficient or $25 \%$ with a margin of safety of $75 \%$. These seeds called "pure seeds" are taken before or after threshing, well drained and stored well in bags or attics and kept well by the head of household. Some producers sell some of them and others use them in case of difficulties in the family. This can very often result in some farmers having seed deficits.

The insufficiency of the pure seed on the farms is filled by an external supply of seeds obtained by exchange, donation or purchase in the village or outside the village. Seeds obtained outside the farm are called "foreign seeds". These are not just seeds to fill a farmlevel seed deficit. It is also about seeds intended for the introduction of new varieties on farms.

\section{Criteria for the selection of varieties cultivated in a peasant environment}

Producers use several criteria simultaneously to select the varieties to be grown (table 7) or to abandon those that do not meet their selection criteria (see table 8). Growers grow several varieties each year in response to a variety of agronomic and socio-economic reasons that are not easily separable. 
Management of the variability of the environment

In extensive culture systems, environmental conditions can be very variable. This is the case in Forest Guinea and in Lower Guinea. To manage this variability of environmental conditions, producers use varietal diversity. They cultivate in deep dips, large varieties (djoukémé, soma sandji), in iron-bearing lowlands, iron-tolerant varieties such as CK90, CK801, CK73, NERICA L19 and ORYLUX6, in Mangrove varieties such as ROK5 and KISSAMPENA are found on hillsides, NERICAS hills such as NERICA1, NERICA4, NERICA6 and NERICA8.

\section{Technique and method of seed conservation}

Producers use several techniques to conserve their seeds. The majority of producers surveyed, $85.5 \%$, store their seeds in bags stored on pallets and kept in buildings or in huts. For the minority (14.5\%), the seeds are kept in granaries.

\section{Harvesting and post-harvesting of lowland rice}

The results of the surveys showed that the harvest of rice in the shallows is done when the whole field becomes yellow (85 to $90 \%$ ) and when the seeds become very hard and the test is done to the tooth. Producers use sickles or knives to harvest. The harvested rice is gathered and tied in boots or booties. Thus, most farmers dry rice in the field with straw before threshing and others just after harvest, they proceed to threshing. Threshing is done in threshing areas with the help of battens, on drums or with jute bags. After the threshing operation, they dry the rice on tarpaulins and put it in bags for storage in stores or in boxes (see figure 4). Those who use the granaries put the grains of rice directly in the attics. Surveys have also shown that producers sort and keep their seeds separately in a suitable place and paddy are intended for consumption or sale in another place.

\section{Socio-economic importance of rice in Guinea}

\section{Food importance}

The results of the surveys revealed that rice is the staple food of the rural population in particular and the population of Guinea in general. Rice is produced mainly for human consumption. It is the most consumed cereal in Guinea. More than $100 \mathrm{~kg}$ of rice are consumed per person, per capita and per year. It is consumed in the form of bland rice associated with several sauces based on peanut paste, tomato, cassava leaves, potato leaves, meat and fish. It is also consumed in the form of porridge.

\section{Economic importance}

Rice is a very important source of income for producers. After its use for consumption, it is also produced for marketing. Rice is sold in many forms. It is marketed in the form of seeds by many producers that they sell to farmers, NGOs and sometimes the government). In fact, $1 \mathrm{~kg}$ of seeds can cost up to $10.000 \mathrm{FG}$ or $1.10 \mathrm{US}$ dollars. It is also sold in steamed or bleached form. Parboiled rice is the most popular rice in Guinea and is more expensive than rice imported from Asia. One (1) $\mathrm{kg}$ can cost up to $8000 \mathrm{FG}$ or $0.88 \mathrm{US}$ dollars. Bleached rice is much more popular in the forest region, especially in Macenta, N'zerekore, etc. This retail sale of rice is exclusively carried out by adult women, especially local rice, and wholesale sales in shops and stores are mainly confined to adult and young men $(70 \%)$ whether imported or locally (Figure 5). 
Table.1 Distribution of accessions by respondent by sex, age and activity

\begin{tabular}{|c|c|c|}
\hline & Factors & Number of producers surveyed \\
\hline \multirow{2}{*}{ Age classes } & $\leq 50$ years & 150 \\
& $(50-75$ years $)$ & 70 \\
\hline \multirow{2}{*}{ Genders } & $\geq 75$ years & 30 \\
& Male & 175 \\
& Female & 75 \\
\hline \multirow{3}{*}{ Agricultural and non } & Producers & 90 \\
agricultural activities & Household & 40 \\
& Breeders & 25 \\
& Tradespeople & 25 \\
& Officials & 15 \\
& Maraîchers & 15 \\
& Producers/Maraîchers & 15 \\
& other & 25 \\
\hline
\end{tabular}

Table.2 Rice nomenclature of rice

\begin{tabular}{|c|c|c|c|}
\hline Regions & Ethnic group & Number of producers surveyed & Vernacular or local names \\
\hline \multirow{3}{*}{ Kindia } & Sousous & 65 & Maley \\
\hline & Peuls & 20 & Maaro \\
\hline & Malinkés & 20 & Maalö \\
\hline \multirow{6}{*}{ Macenta } & Toma & 50 & Moléyi \\
\hline & Guerzés & 30 & Mônou \\
\hline & Kissiens & 20 & Malon \\
\hline & Koniankés & 20 & Maalö \\
\hline & Peuls & 12 & Maaro \\
\hline & Mano & 8 & Gbou \\
\hline
\end{tabular}

Table.3 Distribution of accessions by cycle and number of respondents

\begin{tabular}{|c|c|c|c|c|c|c|c|}
\hline $\mathbf{N}^{\circ}$ & Regions & $\begin{array}{c}\text { Number } \\
\text { of CRD }\end{array}$ & $\begin{array}{c}\text { Number of } \\
\text { villages } \\
\text { surveyed }\end{array}$ & $\begin{array}{c}\text { Number of } \\
\text { accessions } \\
\text { collected }\end{array}$ & Ecosystems & $\begin{array}{c}\text { Cycle of } \\
\text { varieties }\end{array}$ & $\begin{array}{c}\text { Number of } \\
\text { respondents }\end{array}$ \\
\hline $\mathbf{1}$ & Kindia & 10 & 17 & 43 & lowland & $3-6$ month & 130 \\
\hline $\mathbf{2}$ & Macenta & 6 & 24 & 47 & lowland & $4-7$ month & 120 \\
\hline
\end{tabular}

Table.4 Area distribution by type of rice production and natural region (in thousands of hectares)

\begin{tabular}{|c|c|c|c|c|c|c|}
\hline Types of rice & $\begin{array}{c}\text { Lower } \\
\text { Guinea }\end{array}$ & $\begin{array}{c}\text { Middle } \\
\text { Guinea }\end{array}$ & $\begin{array}{c}\text { Upper } \\
\text { Guinea }\end{array}$ & $\begin{array}{c}\text { Forest } \\
\text { Guinea }\end{array}$ & Total & Percentage \\
\hline Upland rice & 48 & 32 & 84 & 148 & 312 & $65 \%$ \\
\hline Mangrove rice & 76 & - & - & - & 76 & $16 \%$ \\
\hline Low landrice & 25 & 9 & - & 13 & 47 & $10 \%$ \\
\hline Riz de plaine & - & 7 & 33 & 5 & 45 & $9 \%$ \\
\hline Together Guinea & 149 & 48 & 117 & 166 & 480 & $100 \%$ \\
\hline Percentage & $31 \%$ & $10 \%$ & $24 \%$ & $35 \%$ & $100 \%$ & \\
\hline
\end{tabular}

Source LPDA2, SNSA (1999) (campaign 97/98) 
Table.5 Frequency of obtaining varieties in the two study areas

\begin{tabular}{|c|c|}
\hline Type of introduction & lowland \\
\hline $\begin{array}{l}\text { Exchange } \\
\text { Don } \\
\text { Purchase } \\
\text { Heritage } \\
\text { benefits } \\
\text { public services } \\
\text { Total } \\
\text { unknown }\end{array}$ & $\begin{array}{c}90(36 \%) \\
70(28 \%) \\
40(16 \%) \\
25(10 \%) \\
7(2.8 \%) \\
22(8.8 \%) \\
250(100 \%) \\
4(1.6 \%)\end{array}$ \\
\hline Total & $254(100 \%)$ \\
\hline
\end{tabular}

Table.6 Relations between suppliers and buyers of varieties

\begin{tabular}{|c|c|}
\hline Ecology & lowland \\
\hline Relatives link & $125(49.2 \%)$ \\
Beautiful parents & $75(29.5 \%)$ \\
Friends or neighbors & $30(11.8 \%)$ \\
other & $24(9.4 \%)$ \\
\hline Total & $\mathbf{2 5 4}(\mathbf{1 0 0 \%})$ \\
\hline
\end{tabular}

Relatives link = Father, mother, oncle, ante, brother, sister and cousin

Table.7 Frequency of characters used by growers to select varieties to grow

\begin{tabular}{|c|c|c|}
\hline Criteria & Kindia (lowland) & Macenta (lowland) \\
\hline Short cycle & $20(12.65 \%)$ & $18(12.77 \%)$ \\
Good performance & $30(18.98 \%)$ & $32(22.70 \%)$ \\
Aromatic & $10(6.32 \%)$ & $15(10.64 \%)$ \\
Swelling & $5(3.16 \%)$ & $10(7.09 \%)$ \\
Iron tolerance & $15(9.49 \%)$ & $21(14.89 \%)$ \\
Resistance to egrainage & $8(5.06 \%)$ & $10(7.09 \%)$ \\
Resistance to lodging & $10(6.32 \%)$ & $5(3.55 \%)$ \\
Average cycle & $15(9.49 \%)$ & $12(8.51 \%)$ \\
Swelling during cooking & $20(12.65 \%)$ & $5(3.55 \%)$ \\
Resistance to flood & $10(6.32 \%)$ & $3(2.13 \%)$ \\
Gros grains & $5(3.10 \%)$ & $\mathbf{1 4 1}(\mathbf{1 0 0} \%)$ \\
\hline Total & $\mathbf{1 5 8}(\mathbf{1 0 0 \%})$ & \\
\hline
\end{tabular}


Table.8 Frequency of characters used by producers to abandon cultivated varieties

\begin{tabular}{|c|c|c|}
\hline Criteria & Kindia (lowland) & Macenta (lowland) \\
\hline Very short cycle & $6(33.33 \%)$ & $4(28.57 \%)$ \\
Low yield & $2(11.11 \%)$ & $1(7.14 \%)$ \\
No aroma & $4(22.22 \%)$ & $2(14.28 \%)$ \\
Do not inflate & $1(5.55 \%)$ & 0 \\
Sensitivity to iron & $2(11.22 \%)$ & $1(7.14 \%)$ \\
Sensitivity to the egrainage & $1(5.55 \%)$ & $3(21.42 \%)$ \\
Sensitivity to lodging & 0 & $1(7.14 \%)$ \\
Sensitivity to flood & $1(5.55 \%)$ & $2(14.28 \%)$ \\
Do not swell when cooking & 0 & 0 \\
Smallness of grains & $1(5.55 \%)$ & 0 \\
\hline Total & $\mathbf{1 8}(\mathbf{1 0 0 \%})$ & $\mathbf{1 4}(\mathbf{1 0 0 \%})$ \\
\hline
\end{tabular}

Fig.1 Kindia Region: CRDs and Urban Center

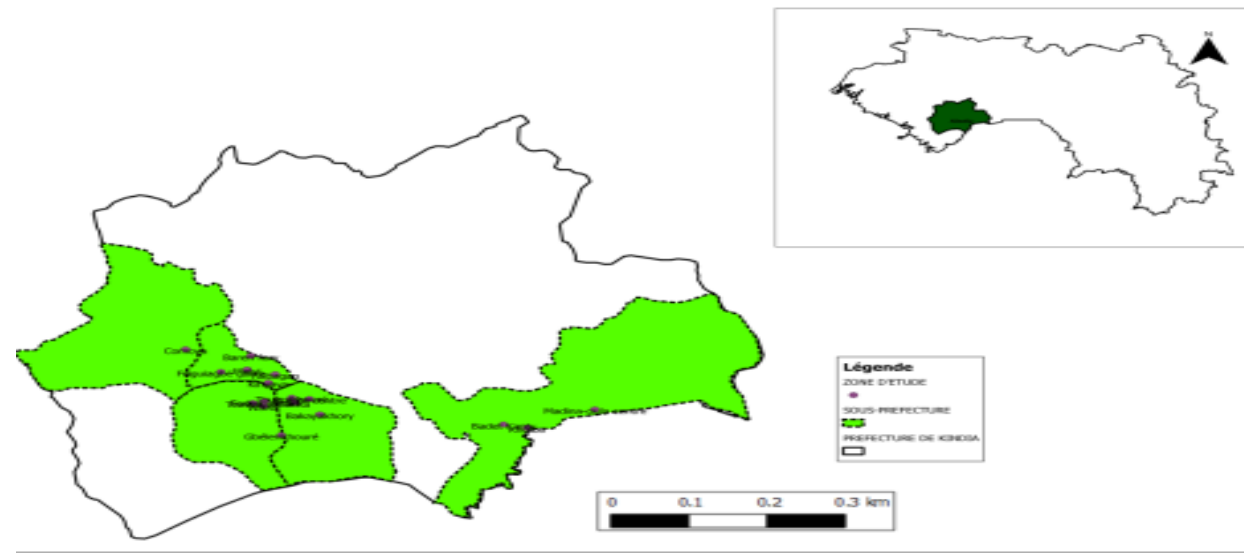

Fig.2 Macenta Region: Seredou Center

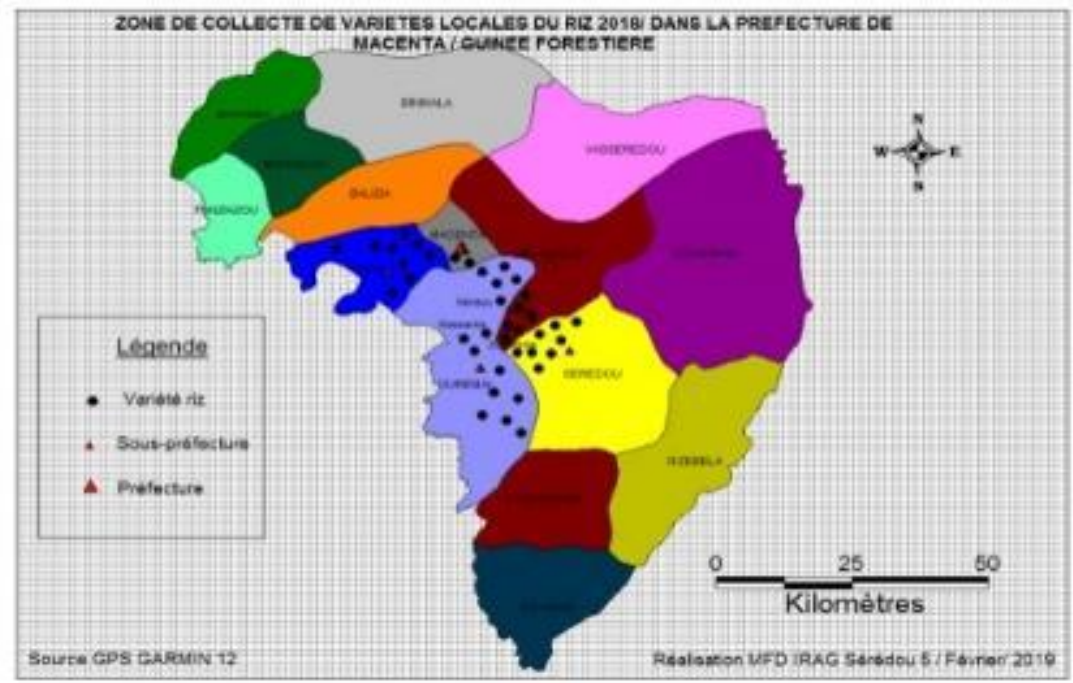


Fig.3 Identifying local varieties of rice among farmers

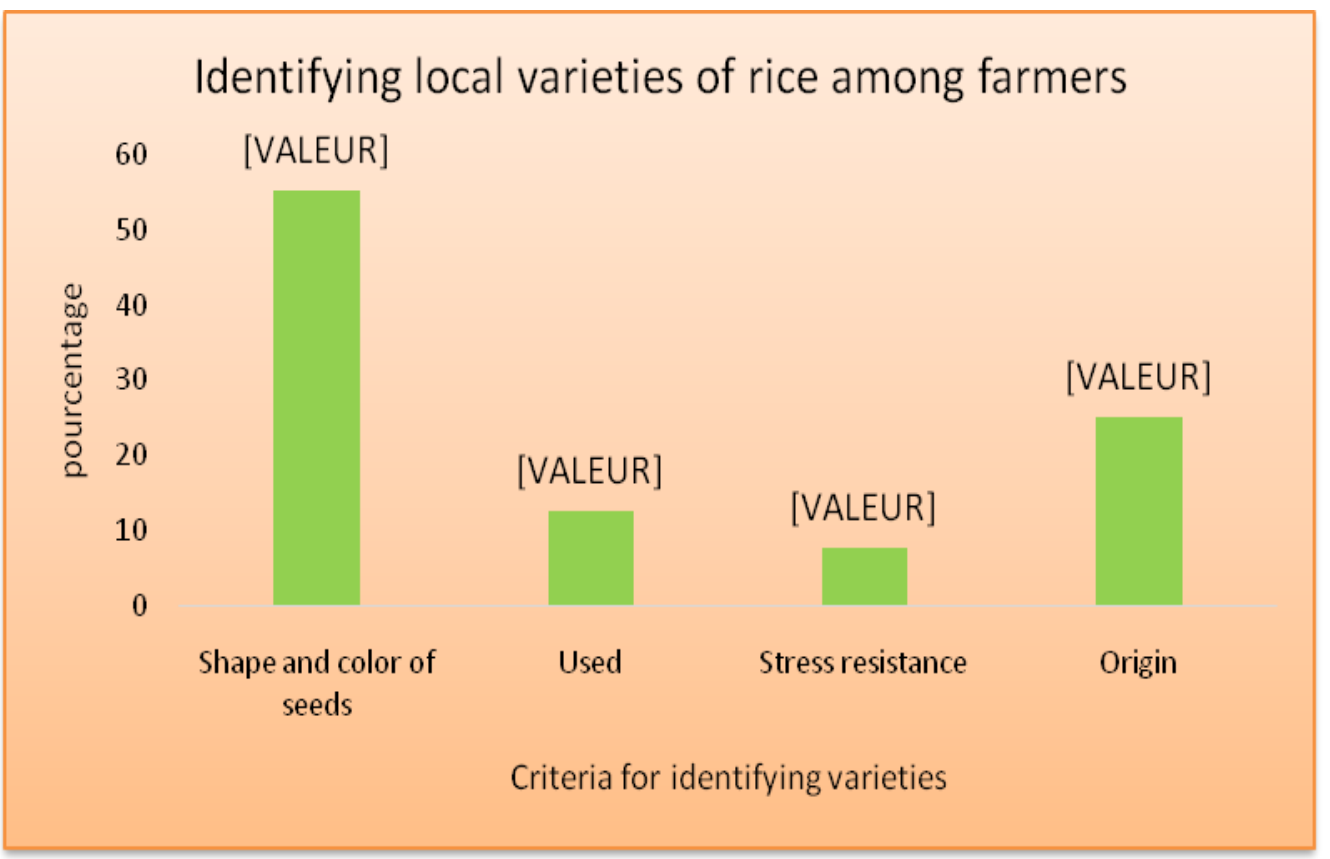

Fig.4 Rice at maturity in the harvest phase and post harvest

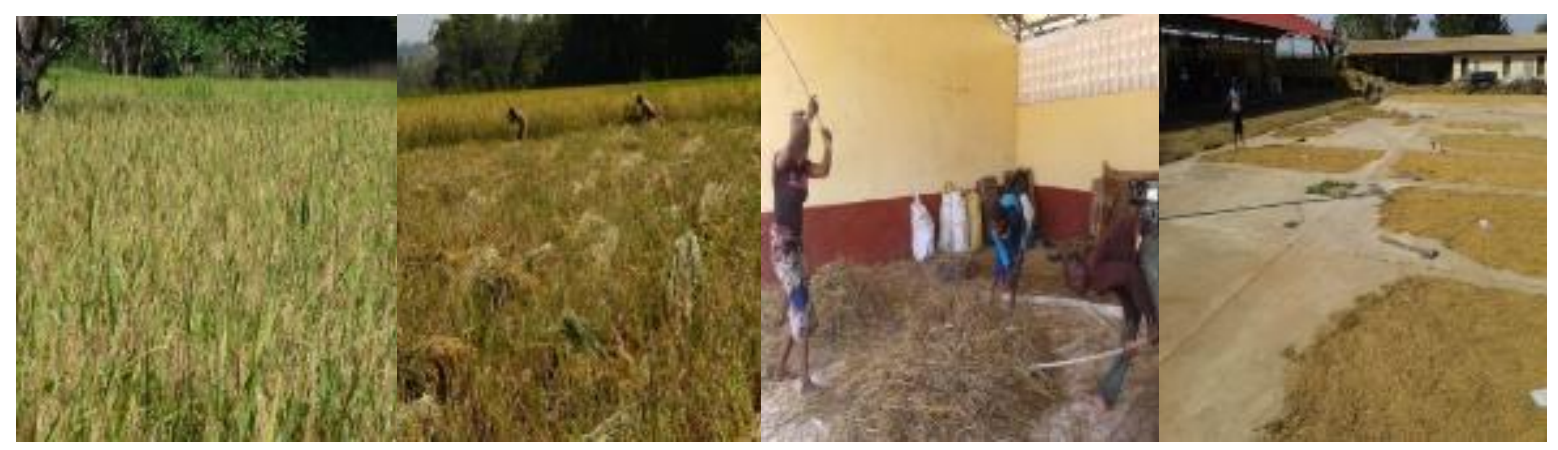

Fig.5 Sale of local parboiled, milled and imported rice in the Kindia and Macenta markets

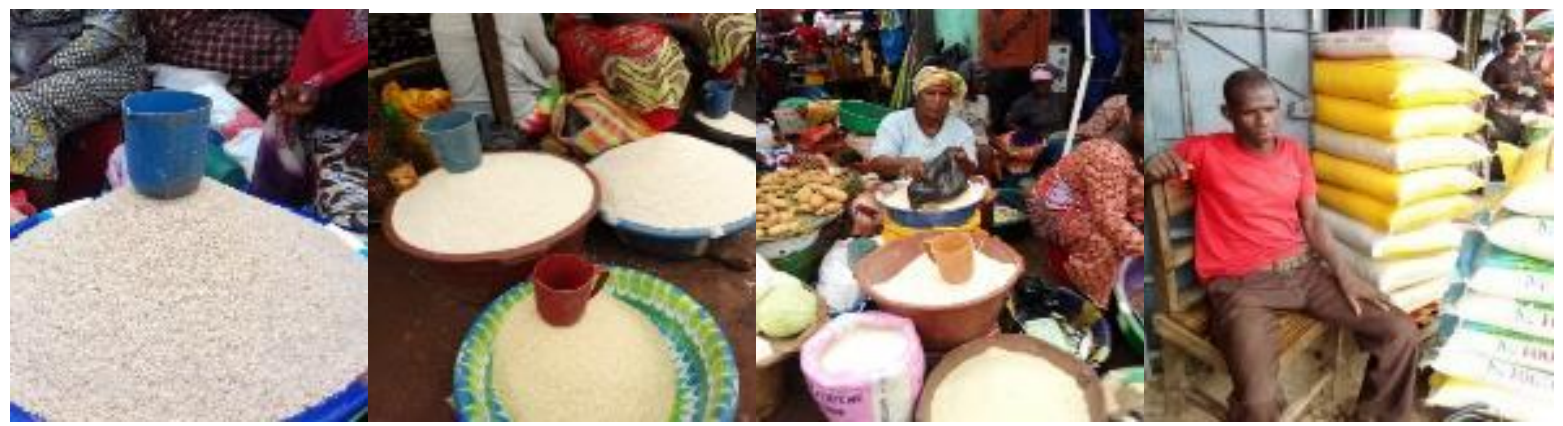


Fig.6 Symptoms of iron toxicity, leaf blast and Diospsis attack

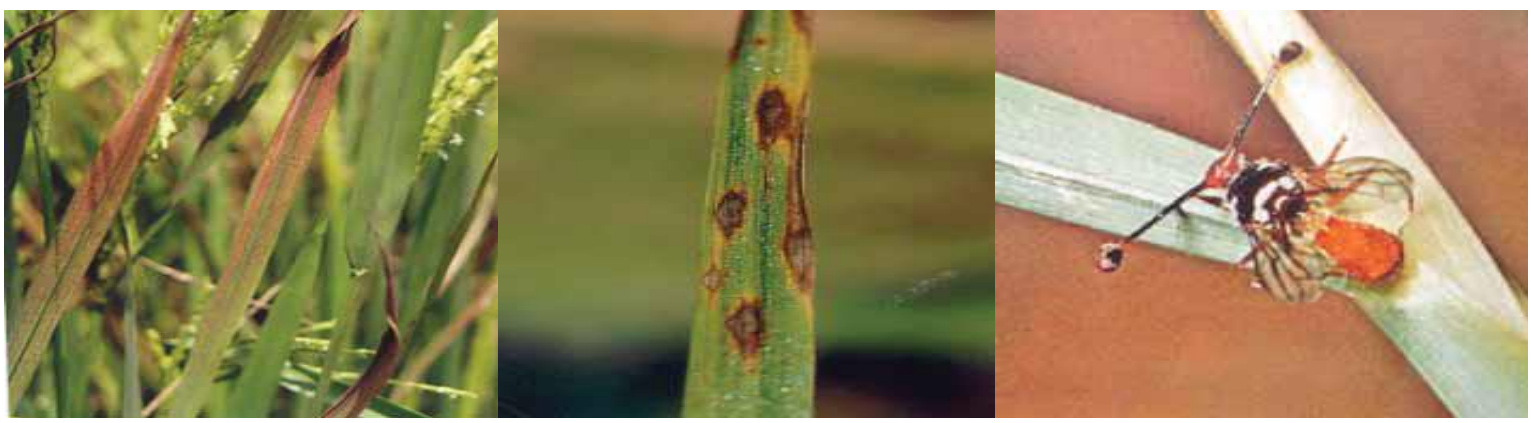

Management of the cultural and food calendar

The cultural calendar is a function of the cycles of varieties. For a large number of varieties with different vegetative cycles, 3 to 6 months in forest Guinea and 4 to 7 months in Lower Guinea, it is necessary and even essential to spread the period of installation of the crop and to make harvests staggered in the time. To program the crop cycle in relation to the 6-month rainy season in Lower Guinea and 8 months in forest Guinea, it is essential that the seedlings of the varieties are made in May-June in Forest Guinea and June-July in Lower Guinea. The sowing of long-cycle varieties is always carried out in the first position because they are the most sensitive to water stress, then follow the semi-early varieties and the early varieties. Late or long cycle varieties are the most productive and are very important in the production of early cycle varieties that allow farmers to ensure the food gap between the end of the reserves and the early ones crops of rice, peanuts or fonio.

\section{Constraints and causes of abandonment of lowland rice varieties}

Surveys indicate that several biotic and abiotic constraints hinder farmers' cultivation of lowland rice. At the level of biotic constraints, weeds, insects, mice, birds and diseases (blast, helminthosporiosis, RYMV, etc.) are reported, whereas iron toxicity, salinity, drought and soil infertility constitute abiotic constraints: The main constraints are weeds and iron toxicity, which currently pose enormous problems for rice producers in the lowlands in Lower Guinea and in Forest Guinea.

Causes of variety abandonment include susceptibility to iron toxicity, ginning, drought, salinity or acidity, low yield and poor grain quality (see Figure 6).

The increase in the number of varieties grown per village in the two surveyed areas (Kindia and Macenta) for the lowland ecosystem observed during the survey is similar to the results reported by Barry et al., (2006a) at the time of the survey an earlier survey conducted in 79 villages belonging to the 4 natural regions of Guinea including Lower Guinea. This increase mainly concerned improved varieties introduced in the 1990s. The increase in the number of varieties per village in the two regions was more noticeable in varieties with an earlier $O$ cycle Sativa while the number of varieties of $O$. glaberrima remained stable by Barry et al., (2006a).

Producers receive many varieties at the same time and therefore do not control the number of varieties they grow at a given time for lack of follow-up.

The introduction of improved varieties does not cause disruption or confusion within variety diversity. The situation in Guinea is 
comparable to those described for other species such as potatoes (Brush et al., 1992), maize (Bellon and Brush, 1994, Louette et al., 1997, Sanou 1996) and rice (Bellon et al., 1998).

The high number of variety denominations thus confirms that these two regions (Lower Guinea and Forest Guinea) are important regions for the conservation of rice genetic resources. Although the richness of names is not necessarily correlated with genetic diversity (Barry et al., 2006d), the variety of names could be a relatively powerful indicator of diversity, particularly in the case of funds.

Of the two species, O. sativa is the most cultivated with higher yields compared to $O$. glaberrima. The presence of African species of cultivated rice is however important information. $O$. glaberrima has completely disappeared in some regions such as in East Africa (Bezançon, 1994). On the other hand, the study revealed that it is still maintained in Guinea, to a considerable degree in these two regions, which are the granaries of Guinea in rice.

This maintenance could be explained by the hardiness of the species and the precocity of the varieties of the species. In fact, according to the producers, the hardy varieties would give important yields in the difficult to exploit environments where the varieties of $O$. sativa could only give very low yields. In deep submersions for example, it is the varieties such as "Djoukémé" in Forest Guinea and "Malodyan" in Lower Guinea, all belonging to O.glaberrima, which are priority crops. This species is also less demanding in nutrients and is less sensitive to stress (ferrous toxicities, drought) than Oryza sativa. In addition, $O$ varieties Glaberrima are more precocious than those of $O$. sativa which are in their majority longer cycle. Producers who do not have much means grow this species to harvest during the food lean period, which is a huge problem for producers.

The creation of new varieties of Oryza sativa species early and the improvement of soil fertility, the maintenance of this species of Oryza glaberrima could be threatened in the ecosystem of low-lying rain. An analysis of the distribution of variety names across the region has shown that a very large majority of variety names are found in a single village. Such a finding has already been made in other rice systems, particularly in India (Pham and Morin, 1998). However, on the origin of varieties, very few of them come from the village where they are grown. This contradiction can be explained by the sampling of the villages or by the denomination of the varieties at the time of their introduction. The second explanation seems to be contradicted by survey results showing that more than $96 \%$ of varieties in Kindia and $98 \%$ in Macenta did not change their name when introduced.

Currently in the villages, the most widespread varieties in lowland ecosystems are mostly improved varieties (70\%). Despite this important introduction, producers always keep the local or traditional varieties they have had for several years.

Analysis of the distribution of varieties in the villages shows that the varieties do not have the same importance. Depending on their level of importance, there are fewer major varieties grown by a large number of producers of large areas and minor varieties, including aromatic varieties only prepared for a category of people such as foreigners, or exotic varieties or old varieties that are endangered. The varieties are indeed better adapted to the conditions of the environment and have a very high level of yield and a better grain quality for consumption (good cooking swelling and good flavor). However, minor varieties are 
poorly adapted to different environmental conditions and are therefore only found in certain areas such as flooded areas.

With regard to the introduction, maintenance and dissemination of varieties, producers first experiment with varieties before they are adopted. This could be explained by the high or low number of introductions and abandonment of varieties on farms in all ecosystems. Farmers seem to be constantly looking for better varieties than the best of the moment. The numerous agroecological and socio-economic constraints that they frequently face justify this attitude in a context of extensive agriculture without the use of agricultural inputs (water, seeds, fertilizers, herbicides, insecticides). Some farmers introduce and abandon varieties more frequently than others. This difference in farmers behavior regarding the introduction of varieties could be interpreted as an opposition between innovators and conservatives. Farmers do not take at random the new varieties introduced in their village. Before any decision of introduction or rejection of a given variety, the producers first observe it in the fields of the producers who test it.

The lowland ecosystem is the most important because it contains more genetic material, it is a very productive and very important ecosystem for the protection of the environment. The need for varietal diversity would be even greater in this ecosystem because of the greater variability of environmental conditions and especially of its productivity. Heterogeneity of the environment is a frequently advanced factor in maintaining varietal diversity (Bellon et al., 1997), particularly in rice (Lando and Mak, 1994). The dissemination of varieties is very often carried out by the producers and the services of the State. The action of the producers is realized between producers through the traditional mechanisms of exchange of plant material. The results of our surveys show the proximity link and the importance of non-market exchanges. The action of the state services is carried out by research through experimentation in the peasant environment and by the extension services in a very punctual way. The informal system of dissemination concerns the producers of all the villages of the two regions on a continuous basis, it is the most important while the formal system is discontinuous but affects only a very small number of producers. These two systems complement each other. When a given variety is introduced into a village by state services, it automatically enters the informal dissemination process. The life of a variety at a village and regional scale is thus the result of an interaction between individual and collective processes.

Despite all the introductions of the new varieties and the richness of the variety diversity, the problem of iron toxicity persists in all the lowlands of these two regions and the traditional varieties contain in their turn many insufficiencies. Lowlands are abandoned in many places in these two regions by the producers.

The present analysis of the dynamics of varietal diversity of rice namely the variety richness, the methods of characterization and naming of varieties by farmers, the use made of varietal diversity, the methods of supply, production and seed renewal in the Kindia and Macenta regions revealed that the factors influencing the management of rice varieties and seeds by farmers in the shallows are biotic and abiotic stresses including iron toxicity. This is to feed reflection on the conservation and sustainable management of varietal diversity in Guinea.

The information collected on varietal profiles from farmers who own the varieties has proved that all the varieties collected are local 
and not improved. The knowledge thus collected should make it possible to identify the key processes of farmers maintenance of rice diversity, to detect any unfavorable developments and to formulate a conservation strategy for genetic resources compatible with the necessary increase in rice productivity in a peasant environment.

These local varieties collected in these different localities of the Kindia and Macenta regions in farmland could be used as plant material for the test of tolerance and or resistance to iron toxicity in the lowlands in Kilissi and Sérédou.

\section{Acknowledgement}

We sincerely thank WAAPP / WAAPP for funding our work, the Biosciences Laboratory of Joseph KI-ZERBO University as well as IRAG, for technical support and various corrections to the manuscript.

\section{References}

Abdoul K.C., 2006.Test et développement des variétés de riz tolérantes à la toxicité ferreuse en basse Guinée. Dans : Audebert A, Narteh LT, Kiepe P, Millart D, Beks B (eds) Toxicité ferreuse dans les systèmes à base riz d'Afrique de l'Ouest, Africa Rice Center (WARDA), pp 68-81

Adrao, 2002. Toxicité ferreuse dans les basfonds: la rouille du riz. Rapport annuel, Points saillants des activités, 37p.

Adrao, 2002. Toxicité ferreuse dans les basfonds: la rouille du riz. Dans: ADRAO. Points saillants des activités. Rapport annuel 2001-2002. ADRAO, Bamako, pp. 29-37.

Africarice, 2013. La science rizicole pour la sécurité alimentaire à travers le renforcement de l'agriculture familiale et l'agro-industrie en Afrique, $3^{\text {ème }}$ Congrès du riz en Afrique, 21-24
Octobre 2013, Yaoundé (Cameroun), $296 \mathrm{p}$.

Anasa, 2010. Agence Nationale des Statistiques Agricoles et al.,imentaires. Rapport national, Conakry, République de Guinée, 33p.

Anasa, 2012. Agence Nationale des Statistiques Agricoles et al.,imentaires. Rapport synthèse, Conakry, République de Guinée, 11p.

Audebert A., 2006. Répartition du fer comme mécanisme de tolérance à la toxicité ferreuse en riziculture de bas-fond. CIRAD-CA UPR Riziculture, Montpellier, France In: ADRAO, 35p.

Audebert, A. Narteh L.T., Kiepe. P., Milla R. et Beks D.B., 2006. Toxicité ferreuse dans les systèmes à base riz d'Afrique de l'Ouest. ADRAO, Cotonou (Bénin), $196 \mathrm{p}$.

Ahmadi, N., Becquer, T., Larroque, C., Arnaud, M., 1988. Variabilité génétique du riz (OryzasativaL.) à Madagascar. L'agronomie tropicale 43, pp. 209-221.

Aulong S., Figuières C., Thoyer S., 2006. Agriculture production versus biodiversity protection: what role for north-south unconditional transfers, World Congress of Environmental and Resource Economists, Kyoto.

Bagayogo A., 2011. Evaluation et Sélection variétale participatives de nouvelles variétés tolérantes à la toxicité ferreuse et aux principaux ravageurs (Insectes et maladies) sur les périmètres rizicoles de Nena Dionkélé (Bas-fond) et de la Vallée du Kou (irriguée). Mém. de fin de cycle, Institut du Développement Rural, 01 B.P. 091 Bobo Dioulasso 01. Université Polytechnique de BoboDioulasso, Burkina Faso, 65 p.

Barry M. B., 2006. Diversité et dynamique des variétés locales de riz (O. Sativa \&O. glaberama) en Guinée, Conséquences 
pour la conservation des ressources génétiques, Thèse de Doctorat, Ecole nationale supérieure agronomique de Rennes, France, 158p.

Briat J.F. et Vert G., 2004. Acquisition et gestion du fer par les plantes. Cahiers Agricultures, Vol. 13, pp. 183-201.

Barnaud A., Joly H.I., Mckey D. (2000-3500 MM D'EAU PAR AN) AVEC 8 MOIS DE PLUIE DE MARS À OCTOBREDEU M. KHASAH C., MONNÉ S., GARINE E., 2008. Gestion des ressources génétiques du sorgho (Sorghum bicolor) chez les Duupa (Nord Cameroun). Cahiers d'études et de recherches francophones/Agricultures 17, pp. 178182.

Barry M., Pham J., Noyer J., Billot C., Courtois B., Ahmadi N., 2007. Genetic diversity of the two cultivated rice species $(O$. sativa \&O. glaberrima) in Maritime Guinea. Evidence for interspecific recombination. Euphytica 154, pp. 127-137.

Barry M.B., Diagne A., Pham J.-L., Ahmadi N., 2008. Évolution récente de la diversité génétique des riz cultivés (Oryzasativa et $O$. glaberrima) en Guinée. Cahiers d'études et de recherches francophones / Agricultures 17, pp. 122-127.

Barry M.B., Diange A., Sogbossi M.J., Pham J.L., Diawara S. and Ahmadi N., 2006A. Recent evolution of varietal diversity of rice in Guinea. New descriptors for the monitoring of in situ diversity in crop plant.

Barry M.B., Pham J.L., Courtois B., Billot C. and Ahmadi N., 2006e. Genetic diversity of cultivatedrice ( $O$. sativa and $O$. glaberrima) at the village and at the farmlevels. Consequences for conservation of rice genetic resources.

Bellon M.R., Phamj.L. and Jackson M.T.C'EST UNE ZONE TRÈS
FAVORABLE À L'AGRICULTURE À TRAVERS LA RICHESSE DES SOLS EN ÉLÉMENTS NUTRITIFS ET UNE PLUVIOMÉTRIE ABONDANTE (2000-3500 MM D'EAU PAR AN) AVEC 8 MOIS DE PLUIE DE MARS À OCTOBRE, 1997. Genetic conservation: a role for rice farmers. In: N. Maxted, B.V. Ford-Lloyd \& J.G. Hawkes (eds), Plant Conservation: the In Situ Approach. Chapman \& Hall, London, pp. 263-289.

Bellon M. R., Pham J.L., Sebastian L.S., Francisco S.R., Loresto G.C., Erasga D., Sanchez P., Calibo M., Abrigo G., Quilloy S., 1998. Farmers' perceptions of varietal diversity: implications for on-farm conservation of rice. In S. Smale (ed), Farmers, Gene Banks and Crop Breeding. Kluwer AcademicPublishing pp. 95-108.

Bezançon G., 1994. Le riz cultivé d'origine africaine (Oryza glaberrima Steud) et les formes sauvages et adventices apparentées: diversité, relations génétiques et domestication. Thèse de Doctorat d'Etat. Université de ParisSud (Centre d'Orsay). TDM n'115, ORSTOM éditeur, 232p.

Bezançon G. and Koffi G., 1979. Prospection des riz africains. Campagne 1979. Mission de prospection en république populaire et révolutionnaire de Guinée, 15 Novembre - 30 décembre 1979. 28 p.

Brush, Meng E., 1998. Farmers evaluation and conservation of crop genetic resources. Genetic Resources and Crop Evolution 45, pp. 139-150.

Ministere du Plan, Direction Nationale des Statistiques, 2010. Rapport national sur le recensement général de la population, Conakry, Guinée, 287p.

Diatta S. A., Audebert K. L., Sahrawat and Traoré S., 1998. Lutte contre la 
toxicité ferreuse du riz dans les basfonds. Acquis de l'ADRAO dans la zone des savanes Afrique de l'Ouest. Aménagement et mise en valeur des bas-fonds au Mali, 21-25/10/96, Sikasso, Mali, CIRAD-CA.

FAO, 2007. Elaboration d'un programme d'assistance technique pour les pays de l'Afrique de l'Ouest. Rapport pays République de Guinée, Conakry, 217p.

Gheysens S. and Bertin P., 2009. Impact $d u$ silicium sur l'expression de la toxicité ferreuse chez le riz cultivé (Oryza sativa L.). Mém. présenté en vue de l'obtention du grade de Bio-ingénieur. Université Catholique de LOUVAIN, Faculté d'ingénierie biologique, Agronomique et environnementale, $100 \mathrm{p}$.

Ghesquère A., Second G., 1983. Polymorphisme enzymatique et évolution d'Oryza sativa en Afrique. In Colloque Electrophorère et taxonomie. Société Zoologique de France, pp. 83-90.

Godon P., 1991. Histoires de riz: les variétés. Publié dans Kalum-scop, bulletin trimestriel de la Mission Française de Coopération et d'Action Culturelle, Conakry, Guinée, $6 \mathrm{p}$.

Guissou R., Ilboudo F., 2012. Analyse des incitations et pénalisations pour le riz au Burkina Faso. Les sols rouges sur sables et sur grès d'Afrique occidentale. Série notes techniques, SPAAA, FAO, Rome. Journal D'HOORE, 44p.

IFDC, 2010. Fiche d'information, publication conjointe du Projet MIR Plus UEMOA-CEDEAO, mise en œuvre par l'IFDC, $\mathrm{N}^{\circ} 6$, IFDC, Ouagadougou, Burkina Faso, 1p.IFDC, 2011. Fiche d'information, publication conjointe du Projet MIR Plus et l'Initiative PPU/SAADA menée par le Programme de Gestion des Ressources Naturelles de l'IFDC. Fiche d'information, N6, IFDC, Ouagadougou, Burkina Faso, $4 p$.

IFS, 2001. GUINEE: Initiative pour la fertilité des sols (IFS) Plan d'action nationale. Rapport d'atelier de validation du 29 et 30 mai 2001 à Conakry (Guinée), 41p.

IRRI, 2008. Nutritional recommendations for rice. Botanical name: Oryza sativa $L$. French: Riz. Spanish: Arroz; Italian: Riso; German: Reis, 84p.

Konate K. A., 2012. Criblage de variétés du riz africain (O. Glaberrima) pour la résistance à la toxicité ferreuse sur le périmètre rizicole de la Vallée du Kou. Mém. de fin d'étude. Master en protection et amélioration des plantes, Univ.de Ouagadougou, (Burkina Faso, $60 \mathrm{p}$

Kone B. A., 2010. Evaluation de la tolérance de variétés de riz à la toxicité ferreuse et aux ravageurs (insectes et maladies) sur les périmètres rizicoles de Banfora (bas-fond) et de la vallée du Kou (irriguée) et tests de sélection variétale participative. Institut du Développement Rural, Univ. Polytechnique de Bobo-Dioulasso, Burkina Faso, 72p.

Lando R.P. and Mak S., 1994. Cambodian farmersdecisionmaking in the choice of traditional rainfed lowland rice varieties. IRRI Research Paper Series 154 pages.

Louette D., Charrier A. and Berthaud J., 1997. In situ conservation of maize in Mexico: Genetic diversity and maize seed management in a traditional community. Econ. Bot. 51(1): pp. 2038.

Météo Kindia, 2018. Service Régional de la Météorologie de Kindia, Guinée.

Monographie Nationale, 2000. Monographie nationale de l'horticulture, Conakry, République de Guinée, 237p.

Oldfield M.L., Alcorn J.B., 1987. 
Conservation of traditional agroecosystems. Bioscience 37, pp. 199-208.

Ouattara S. A., 1995. Contribution à l'étude des bactéries réductrices du fer et du sulfate dans les sols de rizière de la Vallée du kou (Burkina Faso).Thèse de doctorat: Mention Sciences (Biologie Cellulaire-Microbiologie). Univ.de Provence Aix-Marseille 1, Paris, 149p.

Portères R., 1966. Les noms des riz en Guinée. Journal d'Agriculture Tropicale et de Botanique Appliquée, 13p.

Sanou J., 1996. Analyse de la variabilité génétique des cultivars locaux de maïs de la zone de savane Ouest africaine en vue de sa gestion et de son utilisation. Thèse de Doctorat de l'Ecole

Nationale Supérieure Agronomique de Montpellier.

Sawadogo J. B., 1999. Rapport portant sur la vérification des superficies parcellaires du périmètre d'ITENGA. IIMI/PMI-BF, 122p.

Sie M., Saito K., Kone B., Chabi A., Dakouo D., Annan-Afful E., Monh S., Abo E., and Drame K. N., 2010. Coping with iron toxicity in the lowlands of subSaharan Africa: Experience from Africa Rice Center. Second Africa Rice Congress, Bamako, Mali: Innovation and Partnerships to Realize
Africa's Rice Potential, 8p.

Sie M., 1982. Les différents types de rizicultures pratiquées en Haute Volta et leur amélioration. Rapport de synthèse, INERA, Station de FarakoBâ, Bobo-Dioulasso, Burkina Faso, $11 \mathrm{p}$.

SNSA, 2003. Service National des statistiques Agricoles, Rapport national, Conakry, République de Guinée, 11p.

Sanni K., Fawole I., Guei R., Ojo D., Somado E., Tia D., Ogunbayo S., Second G., 1985. Evolutionary relationships in the sativa group of Oryza based on isozyme data. Genet. Sel. Evol. 17, pp. 89-114.

Second G., 1985. Relations évolutives chez le genre Oryzaet processus de domestication. ORSTOM, Paris, Paris, collection étude et thèses, $189 \mathrm{p}$.

Vizier J. F., 1989. La toxicité ferreuse dans les sols de rizières: importance $d u$ problème, causes et mécanismes mis en jeu conséquences pour l'utilisation des sols. Antenne ORSTOM auprès du CFA. DB-SRA Cadarache, France, $13 p$.

Yombouno A. et Bah S., 2012. VECO West Africa, Rapport synthèse étude de la filière riz en Guinée, Conakry, République de Guinée, 67p.

\section{How to cite this article:}

Mamadou Laho Barry, Kiswendsida Romaric Nanema, Kouka Fidèle Tiendrebéogo, Nerbéwendé Sawadogo, Mahamadi Hamed Ouedraogo, Mamadou Billo Barry, Pauline Bationo-Kando and Mahamadou Sawadogo. 2019. Prospecting Collection and Ethnobotanical Studies of Traditional Rice Varieties in Guinea. Int.J.Curr.Microbiol.App.Sci. 8(12): 809-825. doi: https://doi.org/10.20546/ijcmas.2019.812.105 